University of Pittsburgh School of Law

Scholarship@PITT LAW

\title{
The Circulation of Judgments Under the Draft Hague Judgments Convention
}

Ronald A. Brand

University of Pittsburgh School of Law, rbrand@pitt.edu

Follow this and additional works at: https://scholarship.law.pitt.edu/fac_articles

Part of the Comparative and Foreign Law Commons, Conflict of Laws Commons, Courts Commons, Dispute Resolution and Arbitration Commons, International Economics Commons, International Law

Commons, International Trade Law Commons, Jurisdiction Commons, Jurisprudence Commons, Law and Economics Commons, Law and Society Commons, Litigation Commons, Political Economy Commons, Rule of Law Commons, and the Transnational Law Commons

\section{Recommended Citation}

Ronald A. Brand, The Circulation of Judgments Under the Draft Hague Judgments Convention, Unpublished (2019).

Available at: https://scholarship.law.pitt.edu/fac_articles/453

This Article is brought to you for free and open access by the Faculty Publications at Scholarship@PITT LAW. It has been accepted for inclusion in Articles by an authorized administrator of Scholarship@PITT LAW. For more information, please contact leers@pitt.edu, shephard@pitt.edu. 


\title{
The Circulation of Judgments Under the Draft Hague Judgments Convention
}

\author{
Ronald A. Brand ${ }^{*}$
}

\begin{abstract}
The 2018 draft of a Hague Judgments Convention adopts a framework based largely on what some have referred to as "jurisdictional filters." Article 5(1) provides a list of thirteen authorized bases of indirect jurisdiction by which a foreign judgment is first tested. If one of these jurisdictional filters is satisfied, the resulting judgment is presumptively entitled to circulate under the convention, subject to a set of grounds for non-recognition that generally are consistent with existing practice in most legal systems. This basic architecture of the Convention has been assumed to be set from the start of the Special Commission process, and will be key to the Convention's acceptability to countries which might ratify or accede to any final Convention. An alternative approach to convention architecture, which would allow the test for judgment circulation to be built on as few as four rules, was considered and passed over in the earlier Working Group which preceded the Special Commission process. This article discusses the advantages and disadvantages of each of the $2018 \mathrm{draft}$ Convention text as well as the alternative approach. It then suggests that, no matter which approach one considers to be better, the 2019 Diplomatic Conference should begin with an awareness of both options, and an understanding of the advantages and disadvantages of each, and move forward with a clear decision that the option chosen is the best alternative. Such consideration may (1) lead to the conclusion that the choices already made are the best for a multilateral treaty; (2) result in a determination that an alternative approach is a better option; or (3) demonstrate that one

* Chancellor Mark A. Nordenberg University Professor, John E. Murray Scholar, and Director, Center for International Legal Education, University of Pittsburgh School of Law. The author was a member of the U.S. delegation to the Judgments Project negotiations at the Hague Conference on Private International Law in both the Working Group and the Special Commissions prior to the May 2018 Special Commission and has participated in numerous conferences concerning the Hague Judgments Project. The statements in this article are those of the author alone, made in his personal capacity, and should in no way be taken to reflect the position of the United States in the negotiations. The author thanks Peter Trooboff for useful comments on a prior draft.
\end{abstract}


approach works best for some legal systems while another approach works best for other legal systems - leading to dual texts that could form the bases for differing bilateral and multilateral treaty relationships across the globe, while still improving the global framework for the recognition and enforcement of foreign judgments. 


\section{The Circulation of Judgments Under the Draft Hague Judgments Convention}

\section{Table of Contents}

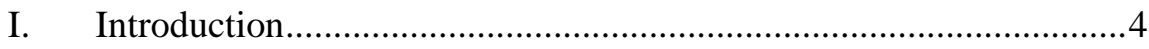

II. The History of the Hague Judgments Project ....................................

III. The May 2018 Draft Text for a Convention on the Recognition and Enforcement of Judgments in Civil and Commercial Matters

A. The General Framework.......................................................10

B. The Article 5(1) Threshold for Judgment Circulation

Under the Convention............................................................12

IV. An Alternative Approach for Article 5(1) .....................................17

V. Assessing the Alternatives .............................................................18

A. Advantages of the May 2018 Article 5(1) Text........................18

1. A comprehensive and exhaustive set of bases of indirect jurisdiction ......................................................18

2. Predictability through clear statement ..............................18

3. Adoption of the majority legal system model ...................19

B. Disadvantages of the May 2018 Article 5(1) Text .....................19

1. The risk of locked-in treaty text ........................................19

2. The risk of "homeward trend" interpretation ....................20

3. The risk of assuming effective legal system

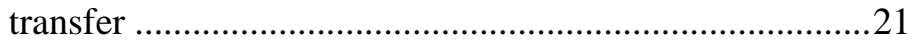

4. The risk of favoring discriminatory jurisdictional schemes over reciprocity .................................................21

5. The risk of a diminished channeling function ...................30

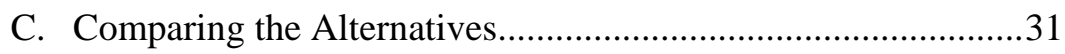

D. The Difficult Political Question ..............................................33

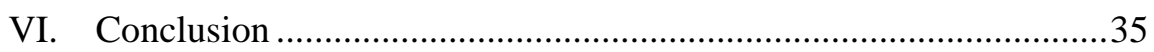




\section{INTRODUCTION}

The recognition and enforcement of foreign judgments has been the subject of multilateral negotiations at the Hague Conference on Private International Law since 1992, when the United States requested that a global approach to jurisdiction and judgments recognition be placed on the negotiating agenda. ${ }^{1}$ With the 2005 Hague Convention on Choice of Court Agreements now in effect in Mexico, Singapore and the 28 countries of the European Union, ${ }^{2}$ a second Judgments Project has moved through the Special Commission stage at the Hague Conference on Private International Law. $^{3}$ The May 2018 draft text of a Convention on the Recognition and Enforcement of Judgments in Civil and Commercial Matters will be considered at a Diplomatic Conference in summer 2019. ${ }^{4}$ That draft text creates a framework based largely on what some have referred to as "jurisdictional filters." Article 5(1) provides a list of thirteen authorized bases of indirect jurisdiction by which a foreign judgment is first tested. If one of these jurisdictional filters is satisfied, the resulting judgment is presumptively entitled to circulate under the convention, ${ }^{5}$ subject to a set of grounds for non-recognition that generally are consistent with existing practice in most legal systems. ${ }^{6}$

${ }^{1}$ The discussion of judgments recognition at the Hague Conference actually began much earlier with a Convention on the Recognition and Enforcement of Judgments in Civil and Commercial Matters completed in 1971, but never entering into effect. See Ronald A. Brand \& Paul M. Herrup, The 2005 Hague CONVENTION ON CHOICE of COURT AgReEMENTS ch. 1 (Cambridge University Press 2008).

2 Hague Convention of 30 June 2005 on Choice of Court Agreements, https://www.hcch.net/en/instruments/specialised-sections/choice-of-court.

3 See Hague Conference on Private International Law, The Judgments Project, https://www.hcch.net/en/projects/legislative-projects/judgments.

${ }^{4}$ Hague Conference on Private International Law, Special Commission on the Recognition and Enforcement of Foreign Judgments, 2018 Draft Convention, https://assets.hcch.net/docs/9faf15e1-9c36-4e57-8d56-

12a7d895faac.pdf. See also https://www.hcch.net/en/projects/legislativeprojects/judgments/22nd-diplomatic-session.

${ }^{5}$ Id. art. 5(1).

${ }^{6}$ Id. art. 7. 
There are a number of important decisions to be made by the 2019 Diplomatic Conference. These include: (1) whether judgments on intellectual property rights will be included within the scope of the Convention, and, if so, how they will be dealt with; (2) whether any Convention provision will address the question of mutual trust, either by allowing differing bilateral relationships or requiring that any new Contracting State receives the benefits of the Convention in all other Contracting States; and (3) the relationship of the Convention with other international instruments. These issues have received attention, both in commentary and in the draft Explanatory Report on the Convention text. ${ }^{7} \mathrm{~A}$ matter that has not received as much attention, but nonetheless is of key importance deals with the basic architecture of the Convention; i.e., how the Convention identifies which foreign judgments are entitled to recognition and enforcement. That architecture will significantly influence the treaty's acceptability to the Member States and other countries that might ratify or accede to the final text. The May 2018 draft text represents one approach to convention architecture by establishing the basic test for circulation of a foreign judgment through a complex set of thirteen jurisdictional filters. The building of the Convention text around that choice is significant, but has received limited comment.

An alternative approach to convention architecture, which would allow the test for judgment circulation to be built on as few as four rules, was considered and passed over in the earlier Working Group. ${ }^{8}$ The first three rules in such an alternative would state simple "fairness" tests, binding a judgment debtor to (1) decisions of the judgment debtor's home court; (2) decisions of the court in which the judgment debtor initiated the action; and (3) decisions of a court to which the judgment debtor expressly consented to jurisdiction. These three bases of jurisdiction reflect the common elements of general jurisdiction throughout the world as a result of the plaintiff's territorial home, and party consent. They are for the most part non-controversial in comparative jurisdictional jurisprudence. They provide

${ }^{7}$ See, e.g., Mayela Celis, HCCH Revised Draft Explanatory Report (version of December 2018) on the Judgments Convention is available on the HCCH website (Jan. 20, 2019), http://conflictoflaws.net/2019/hcch-revised-draftexplanatory-report-version-of-december-2018-on-the-judgments-convention-isavailable-on-the-hcch-website/.

${ }^{8}$ The author was a member of the Working Group. 
respect for jurisdiction based on the choice of the party against whom a judgment may be recognized and enforced.

The fourth rule in the alternative approach to convention architecture would replace ten of the thirteen jurisdictional filters in Article 5(1) with a single rule that would provide the indirect jurisdiction test for what is commonly referred to as special or specific jurisdiction. Rather than attempting to define all of the possible acceptable bases of indirect jurisdiction for the life of the Convention, such a provision would state a simple rule of non-discrimination. If the court addressed would have allowed personal jurisdiction over the defendant on the facts existing in the court of origin (i.e., if jurisdiction would have existed under direct jurisdiction rules of the state of the court addressed based on the existing facts as determined by the court of origin), then the court addressed must acknowledge the legitimacy of the basis of jurisdiction in the court of origin and honor the resulting judgment. In other words, a Contracting State's rules of indirect jurisdiction, for determining recognition and enforcement of foreign judgments, would be the same as that States rules of direct jurisdiction for determining whether to take the case as the originating court. Each Contracting State would thus be compelled to acknowledge, as to its partner Contracting States, that, if a rule of jurisdiction is found to be acceptable at home, it must be found to be acceptable in other Contracting States.

The May 2018 draft text list of jurisdictional filters offers apparent advantages in that it provides an exhaustive list of available indirect bases of jurisdiction, creates predictability in international litigation by having the list available when a case is initiated, and conforms (in part) to the predominant legal system model - continental European civil law. ${ }^{9}$ Nonetheless, it also carries with it several disadvantages.

There are at least five potential disadvantages of the architecture of the current draft Convention. They are:

9 The core instrument in that system is the Brussels I Recast Regulation. Regulation (EU) No 1215/2012 of the European Parliament and of the Council of 12 December 2012 on Jurisdiction and the Recognition and Enforcement of Judgments in Civil and Commercial Matters (Brussels I Recast Regulation), [2012] O.J.E.U. L 351/1, 20 December 2012. 
1) the risk of an exhaustive list which locks in what may become outdated tests that can be changed only by difficult treaty amendment;

2) the risk of diminishing predictability through national court interpretation and the attendant "homeward trend" that has been evident in similar conventions which provide "uniform" rules;

3) the risk of assuming that effective national or regional legal frameworks can automatically be implemented on a global scale;

4) the risk of retention and endorsement of discriminatory jurisdictional schemes applied to judgments recognition rules, thus avoiding normal international trade treaty concepts of reciprocity: and

5) the risk of a diminished channeling function that might otherwise be achieved under a system that encourages uniformity of direct and indirect bases of jurisdiction; i.e., the Convention will not encourage either private parties to alter their litigation conduct or States to reconsider the continuation of exorbitant bases of direct jurisdiction.

No matter which alternative convention architecture one considers to be a better approach, the 2019 Diplomatic Conference should begin with an awareness of the available options and an understanding of the advantages and disadvantages of each, and move forward with a clear decision that the option chosen is the best alternative. Such consideration may lead to the conclusion that the choices already made are the best for a multilateral treaty. It may result in a determination that an approach other than that in the May 2018 Draft Convention Text now appears to be a better option. Or it may demonstrate that one approach works best for some legal systems while another approach works best for other legal systems - leading to dual texts that could form the bases for differing bilateral and multilateral treaty relationships across the globe, while still improving the global framework for the recognition and enforcement of foreign judgments.

\section{The History OF The Hague Judgments Project}

In May of 1992, the United States proposed that the Hague Conference on Private International Law consider preparing a multilateral 
convention on the recognition and enforcement of judgments. ${ }^{10}$ The matter was placed on the agenda of the Hague Conference in October 1996, ${ }^{11}$ resulting in a Preliminary Draft Convention text in October 1999. ${ }^{12}$ That text was revised again at the first part of a split Diplomatic Conference in June 2001. While a new text was created, closely following the 1999 Text, problems with completion were clear from its many bracketed provisions, footnotes, and explanations of various positions. ${ }^{13}$ In April 2002, the Conference instructed an informal working group to consider drafting a more limited convention, including only those jurisdictional provisions on which substantial consensus existed. This resulted in a March 2003 Draft Text on Choice of Court Agreements. ${ }^{14}$ A further Special Commission considered that text, and the Convention on Choice of Court Agreements was concluded at a Diplomatic Conference in June of $2005 .{ }^{15}$

${ }^{10}$ Letter of May 5, 1992 from Edwin D. Williamson, Legal Advisor, U.S. Department of State, to Georges Droz, Secretary General, The Hague Conference on Private International Law, distributed with Hague Conference document L.c. ON No. 15 (92).

${ }^{11}$ Final Act of the Eighteenth Session of the Hague Conference on Private International Law, 19 October 1996, at 21.

12 Informational note on the work of the informal meetings held since October 1999 to consider and develop drafts on outstanding items, drawn up by the Permanent Bureau, Hague Conference on Private International Law, Prel. Doc. No 15 (May 2001) (containing the text of the Preliminary Draft Convention).

13 Hague Conference on Private International Law, Commission II, Jurisdiction and Foreign Judgments in Civil and Commercial Matters, Summary of the Outcome of the Discussion in Commission II of the First Part of the Diplomatic Conference 6-20 June 2001, Interim Text.

${ }^{14}$ Preliminary Result of the Work of the Informal Working Group on the Judgments Project, Hague Conference on Private International Law, Prel. Doc. No 8 (Mar. 2003) (corrected) for the attention of the Special Commission of April 2003 on General Affairs and Policy of the Conference.

15 The text of the Final Act of the Twentieth Session, and a documentary history of the Choice of Court Convention project, are available on the Hague Conference website at: http://www.hcch.net/index_en.php?act=conventions.text\&ci $\underline{\mathrm{d}=98}$. 
The Hague Convention on Choice of Court Agreements went into effect for Mexico and the European Union (for 27 of its Member States) on October 1,$2015 ;{ }^{16}$ for Singapore on October 1, 2016; for Montenegro on August 1, 2018, and for Denmark on September 1, 2018. ${ }^{17}$ The People's Republic of China, Ukraine, and the United States have signed, but have not ratified, the Convention. ${ }^{18}$

The Choice of Court Convention contains three basic rules: Article 5 provides that a court chosen in an exclusive choice of court agreement shall have exclusive jurisdiction; Article 6 provides that a court not chosen shall defer to the chosen court; and Article 8 provides that the courts of all contracting states shall recognize and enforce judgments from a court chosen in an exclusive choice of court agreement, subject to an explicit list of bases for non-recognition found in Article 9. ${ }^{19}$ Thus, the 2005 Convention is both a jurisdiction convention (limited to one basis of jurisdiction: consent to exclusive dispute settlement in the courts of one state) and a judgments convention (providing for circulation of judgments from cases based on exclusive choice of court agreements).

In October 2011, the Council on General Affairs and Policy of the Hague Conference established an Experts' Group to consider the resumption of the Judgments Project. ${ }^{20}$ There was a desire on the part of some delegations to return to the original project and again draft a convention that would deal with both direct jurisdiction and the recognition and enforcement of judgments. In 2012, the Council split these two objectives when it established a Working Group to prepare proposals for a judgments convention and directed the Experts' Group to give further study

${ }^{16}$ On December 28, 2018, the United Kingdom filed an instrument accepting the Convention should its withdrawal from the European Union become effective in March 2019. See HCCH, Status Table, http://www.hcch.net/index_en.php?act= conventions.status\&cid $=98$.

${ }^{17} \mathrm{Id}$.

${ }^{18} \mathrm{Id}$.

${ }^{19}$ For a more complete discussion of the Choice of Court Convention, see BRAND \& HERRUP, supra note 1.

${ }^{20}$ See HCCH, The Judgments Project, https://www.hcch.net/en/projects/legislative-projects/judgments. 
to a separate jurisdiction convention. ${ }^{21}$ The Working Group completed a Proposed Draft Text of a judgments convention in 2016, and the Council established a Special Commission to move the text forward. The Experts' Group was instructed to move forward on a jurisdiction convention only after the judgments convention text would be concluded. ${ }^{22}$ Special Commission meetings for a Judgments Convention were held on June 1-9, 2016; February 16-24, 2017; November 13-17, 2017; and May 24-29, 2018. It is anticipated that a Diplomatic Conference will be held in late June and early July of 2019. ${ }^{23}$

\section{THE MAY 2018 DRAFT TEXT FOR A CONVENTION ON THE RECOGNITION AND ENFORCEMENT OF JUDGMENTS IN CIVIL AND COMMERCIAL MATTERS}

\section{A. The General Framework}

The basic structure of the May 2018 Draft Judgments Convention Text is rather simple, but is then made more complex through the set of indirect jurisdiction filters by which a court is to determine whether a judgment may circulate under the Convention. Articles 1-3 set forth the scope of the Convention and provide definitions. ${ }^{24}$ The Convention applies to "the recognition and enforcement of judgments relating to civil or commercial matters," subject to the exclusions from scope found in Article 2. The scope provisions generally follow those in the 2005 Hague Convention on Choice of Court Agreements, except that the Judgments Convention does not exclude consumer matters from scope.

Article 4(1) provides the operative rule of the Convention, which requires that each Contracting State recognize and enforce judgments from other Contracting States and permits refusal only on those grounds expressly set out in the Convention. The text reads as follows:

${ }^{21} I d$.
${ }^{22} I d$.
${ }^{23} I d$.

24 The May 2018 Draft Text of a Convention on the Recognition and Enforcement of Judgments in Civil and Commercial Matters (reproducing the text set out in Working Document No $262 \mathrm{REV}$ ) is

https://assets.hcch.net/docs/23b6dac3-7900-49f3-9a94-aa0ffbe0d0dd.pdf. 
[a] judgment given by a court of a Contracting State (State of origin) shall be recognised and enforced in another Contracting State (requested State) in accordance with the provisions of this Chapter. Recognition or enforcement may be refused only on the grounds specified in this Convention.

Article 5 then determines which judgments are "eligible for recognition and enforcement" under the convention by providing a list of bases of jurisdiction on which a judgment may have been founded. Thus, the court addressed for purposes of recognition and enforcement indirectly considers the basis of jurisdiction on which the court of origin directly founded its judgment. Each item on the list is effectively adopted as an indirect basis of jurisdiction for purposes of the Convention text. ${ }^{25}$ If the court of origin could have satisfied any one of the jurisdictional tests in the Article 5(1) list, then the judgment is presumptively qualified for recognition and enforcement under the Convention.

Not all of the tests in the Article 5(1) list may necessarily be described as "bases of jurisdiction." For example, the tests in subparagraphs 5(1)(a) (court of defendant's habitual residence), 5(1)(c) (party which brought the principal claim), and 5(1)(e) (party consent), can be described as simple fairness tests by which it can be determined that it is appropriate for the courts of other states to give effect to the resulting judgment. These tests may also be described as rules of comity based in public international law considerations, namely, when should a public body (a court) in one country not interfere with, and instead contribute to making effective, the relationship between a public act (a judgment of a court of another country) and the parties affected by that act.

Article 6 inserts a limited number of direct jurisdiction rules into the judgments convention by providing that in specific instances exclusive jurisdiction exists only in the courts of a single state, and that - in the case of judgments concerning such situations - only judgments from the courts

${ }^{25}$ In the terminology thus used to describe the provisions of Article 5(1), a "direct basis of jurisdiction" is a basis applied in the court of origin, in which the original judgment is rendered. An "indirect basis of jurisdiction" is a basis used by the court addressed when it is asked to grant recognition and enforcement. In this way, bases of indirect jurisdiction are used by the court addressed to test the jurisdiction of the court of origin in order to determine the qualification of the judgment for recognition and enforcement in the court addressed. 
of that state may be recognized and enforced under the Convention. This also effectively provides a rule requiring non-recognition - a judgment from a state other than that with exclusive jurisdiction may not be recognized. Article 7 provides the general bases for non-recognition of a judgment, even if that judgment meets the requirements of Article 5. This list tracks closely the grounds for non-recognition found in the 2005 Hague Choice of Court Convention, ${ }^{26}$ which grounds are generally familiar in national law throughout the world and include such concerns as fraud, lack of proper notice, the existence of inconsistent other judgments, and inconsistency with the public policy of the recognizing state.

Articles 8-17 provide additional rules governing specific circumstances and procedures in an action for recognition and enforcement of a judgment. Articles 18-26 are the "general clauses" for purposes of operation of the Convention. Articles 27-34 are the "final clauses" dealing with ratification, etc.

Articles 4-7 thus contain the basic rules by which judgments will be tested for purposes of recognition and enforcement under the Convention. Of these, if a judgment is within the scope of the Convention under Articles 1 and 2, Article 5(1) then determines the judgments which are eligible for recognition and Article 7 then sets out the bases on which recognition may be denied, even for a judgment otherwise qualified under Article 5. This makes Article 5(1) the door through which a judgment must pass in order to be considered for recognition under the Convention.

\section{B. The Article 5(1) Threshold for Judgment Circulation Under the Convention}

Because of its fundamental role in the Convention architecture, Article 5(1) is likely to be of central concern to any state's determination of whether to ratify the Convention. Thus, the advantages and disadvantages of the Article 5(1) list of jurisdictional filters deserves careful consideration in reaching a final Convention text. In some ways, this provision represents an effort to provide the equivalent of a comprehensive domestic recognition and enforcement statute in an international convention. This is similar to what occurred in the original jurisdiction and judgments project and was found in the 1999 and 2001 texts. When that approach failed to generate a

\footnotetext{
${ }^{26}$ Hague Convention on Choice of Court Agreements, art. 9.
} 
workable text, negotiators sought a different approach, resulting in the 2005 Convention on Choice of Court Agreements. The problems in the 1999 and 2001 draft texts of a comprehensive jurisdiction and judgments convention went far beyond over-drafting, and largely existed because of bracketed text and footnotes indicating both uncertainty and failure of substantive agreement (and, in fact, strong disagreement over the policy and drafting of those provisions). It may be that the two situations are different at this stage of the negotiations, in that the May 2018 Draft Text does not represent the same level of disagreement over policy. Nonetheless, there is similar reason for concern for over-drafting, and it is worth taking a step back and asking whether the May 2018 Article 5(1) text is likely to lead to a Convention that can either achieve broad ratification or be effective if widely ratified.

In order to consider carefully the impact of the May 2018 draft of Article 5(1), it is necessary to consider the length and complexity of its terms, which read as follows:

Article 5

\section{Bases for recognition and enforcement}

1. A judgment is eligible for recognition and enforcement if one of the following requirements is met -

(a) the person against whom recognition or enforcement is sought was habitually resident in the State of origin at the time that person became a party to the proceedings in the court of origin;

(b) the natural person against whom recognition or enforcement is sought had his or her principal place of business in the State of origin at the time that person became a party to the proceedings in the court of origin and the claim on which the judgment is based arose out of the activities of that business;

(c) the person against whom recognition or enforcement is sought is the person that brought the claim, other than a counterclaim, on which the judgment is based;

(d) the defendant maintained a branch, agency, or other establishment without separate legal personality in the State of origin at the time that person became a party to the proceedings in the court of origin, and the claim on which the judgment is based arose out of the activities of that branch, agency, or establishment; 
(e) the defendant expressly consented to the jurisdiction of the court of origin in the course of the proceedings in which the judgment was given;

(f) the defendant argued on the merits before the court of origin without contesting jurisdiction within the timeframe provided in the law of the State of origin, unless it is evident that an objection to jurisdiction or to the exercise of jurisdiction would not have succeeded under that law;

(g) the judgment ruled on a contractual obligation and it was given in the State in which performance of that obligation took place, or should have taken place, in accordance with

(i) the parties' agreement, or

(ii) the law applicable to the contract, in the absence of an agreed place of performance,

unless the defendant's activities in relation to the transaction clearly did not constitute a purposeful and substantial connection to that State;

(h) the judgment ruled on a tenancy of immovable property and it was given in the State in which the property is situated;

(i) the judgment ruled against the defendant on a contractual obligation secured by a right in rem in immovable property located in the State of origin, if the contractual claim was brought together with a claim against the same defendant relating to that right in rem;

(j) the judgment ruled on a non-contractual obligation arising from death, physical injury, damage to or loss of tangible property, and the act or omission directly causing such harm occurred in the State of origin, irrespective of where that harm occurred;

(k) the judgment concerns the validity, construction, effects, administration or variation of a trust created voluntarily and evidenced in writing, and - 
(i) at the time the proceedings were instituted, the State of origin was designated in the trust instrument as a State in which disputes about such matters are to be determined; or

(ii) at the time the proceedings were instituted, the State of origin was expressly or impliedly designated in the trust instrument as the State in which the principal place of administration of the trust is situated.

This sub-paragraph only applies to judgments regarding internal aspects of a trust between persons who are or were within the trust relationship;

(l) the judgment ruled on a counterclaim -

(i) to the extent that it was in favour of the counterclaimant, provided that the counterclaim arose out of the same transaction or occurrence as the claim;

(ii) to the extent that it was against the counterclaimant, unless the law of the State of origin required the counterclaim to be filed in order to avoid preclusion;

(m) the judgment was given by a court designated in an agreement concluded or documented in writing or by any other means of communication which renders information accessible so as to be usable for subsequent reference, other than an exclusive choice of court agreement.

For the purposes of this sub-paragraph, an "exclusive choice of court agreement" means an agreement concluded by two or more parties that designates, for the purpose of deciding disputes which have arisen or may arise in connection with a particular legal relationship, the courts of one State or one or more specific courts of one State to the exclusion of the jurisdiction of any other courts. ${ }^{27}$

${ }^{27}$ The remainder of Article 5 has relevance for consideration of paragraph (1), and reads as follows:

2. If recognition or enforcement is sought against a natural person acting primarily for personal, family or household purposes (a 
consumer) in matters relating to a consumer contract, or against an employee in matters relating to the employee's contract of employment -

(a) paragraph 1(e) applies only if the consent was addressed to the court, orally or in writing;

(b) paragraph 1(f), (g) and (m) do not apply.

[3. Paragraph 1 does not apply to a judgment that ruled on an intellectual property right or an analogous right. Such a judgment is eligible for recognition and enforcement if one of the following requirements is met -

(a) the judgment ruled on an infringement in the State of origin of an intellectual property right required to be granted or registered and it was given by a court in the State in which the grant or registration of the right concerned has taken place or, under the terms of an international or regional instrument, is deemed to have taken place[, unless the defendant has not acted in that State to initiate or further the infringement, or their activity cannot reasonably be seen as having been targeted at that State];

(b) the judgment ruled on an infringement in the State of origin of a copyright or related right, an unregistered trademark or unregistered industrial design, and it was given by a court in the State for which protection was claimed[, unless the defendant has not acted in that State to initiate or further the infringement, or their activity cannot reasonably be seen as having been targeted at that State];

(c) the judgment ruled on the validity[, subsistence or ownership] in the State of origin of a copyright or related right, an unregistered trademark or unregistered industrial design, and it was given by a court in the State for which protection was claimed.]

The brackets around paragraph 3 indicate that the question of the inclusion of intellectual property right (IP) cases within the scope of the Convention is yet to be determined, and this portion of the text remains for further consideration. The problems with IP cases was recently demonstrated in SAS Institute, Inc. v. World Programming Limited, 874 Fed. 3d 370 (4th Cir. 2017) (denying recognition to a UK judgment finding a click wrap agreement prohibiting reverse engineering and 


\section{AN AlternAtive APPROACH FOR ARTICLE 5(1)}

As noted earlier, an alternative approach to Article 5(1) was considered, but not followed, in the Working Group which prepared a draft text for consideration by the Special Commission. The following is an example of how such an alternative approach might look (with the first three tests being quite similar to those found in Article 5(1)(a), (c), and (e) of the May 2018 draft Convention text):

Article 5

Bases for recognition and enforcement

1. A judgment is eligible for recognition and enforcement if one of the following requirements is met -

a) the person against whom recognition or enforcement is sought was habitually resident in the State of origin at the time that person became a party to the proceedings in the court of origin;

b) the person against whom recognition or enforcement is sought is the person that brought the claim on which the judgment is based;

c) the defendant expressly consented to the jurisdiction of the court of origin either prior to or in the course of the proceedings in which the judgment was given; or

d) the dispute in the State of origin was based on facts which would have satisfied a basis of direct jurisdiction available in the State addressed.

This approach would provide for a much simpler Convention architecture, and in that sense is similar to the widely successful New York Arbitration Convention. It also has the virtue of consistency with the approach taken in many Hague Conference Member States. The advantages and disadvantages of each alternative, and whether the four-point alternative approach would be a better Convention architecture, are discussed below.

use for production purposes to be invalid under UK law, on the ground that North Carolina public policy favors the enforcement of contracts). 


\section{Assessing the Alternatives}

\section{A. Advantages of the May 2018 Article 5(1) Text}

At the outset, like any other legal text, Article 5(1) presents factors that may be categorized as both advantages and disadvantages, depending on the purpose one is seeking to achieve. Thus, some of the factors listed as possible advantages in this section will also be discussed as possible disadvantages in the following section.

\section{A comprehensive and exhaustive set of bases of indirect jurisdiction}

Like the 1999 and 2001 texts for a comprehensive jurisdiction and judgments convention, the May 2018 draft of Article 5(1) represents an effort to be exhaustive. Thus, in traditional civil law fashion, the effort largely has been to cover every possible acceptable direct jurisdiction basis as a rule of indirect jurisdiction - i.e., as a jurisdictional filter. To the extent being exhaustive is an advantage in a judgments convention, this is an advantage of the Article 5(1) text. It leaves fewer possibilities for judicial consideration outside the Convention's application. By allowing the recognition and enforcement of judgments beyond those covered by the Convention (except for judgments in violation of the direct jurisdiction rule of Article 6), the Convention presents a floor for judgments recognition purposes, and not a ceiling. ${ }^{28}$ Under Article 16, courts in Contracting States may consider granting recognition and enforcement to judgments beyond those which may be recognized and enforced under the Convention; they simply would not do so by applying Convention rules. ${ }^{29}$ The Article 5(1) list, however, by including thirteen jurisdictional tests, represents an effort to set the floor high.

\section{Predictability through clear statement}

Also like civil law code-type legal instruments, Article 5(1) has been drafted with an eye to predictability. There are clear advantages to having the set of all possible indirect jurisdictional bases allowed under the

${ }^{28}$ May 2018 Draft Text, supra note 24, art. 16 ("Subject to Article 6, this Convention does not prevent the recognition or enforcement of judgments under national law.”).

${ }^{29} \mathrm{Id}$. 
Convention expressly stated rather than acknowledged by implication, as is otherwise possible. A lawyer bringing an action in a case that may require recognition and enforcement in a state other than the state of the court of origin will have a single list of indirect jurisdictional bases to consider. If one of those bases is satisfied, then any resulting judgment would be presumptively eligible for recognition and enforcement in all Contracting States under the Convention.

\section{Adoption of the majority legal system model}

The civil law model on which Article 5(1) is based is the predominant model for judgments recognition law throughout the world. In the Hague negotiations, the European Union has been a leading advocate of this approach, and has proposed many of the provisions of Article 5(1), understandably working to keep the set of jurisdictional filters consistent with current EU law. Conformity with the predominant legal system model presents obvious advantages for future Convention ratification and operation. Because many non-European legal systems have developed from the continental civil law model, it is necessarily the approach more consistent with legal systems in most Hague Member States. The Convention is more likely to be ratified by the EU as a major player in the process, and thus more likely to draw further adherents as a result of having an important lead ratification. As the Brexit process also demonstrates, important common law states have adopted many aspects of the Continental civil law model for jurisdictional rules, thus making the draft text approach to presumptive circulation of a judgment a seemingly natural one.

\section{B. Disadvantages of the May 2018 Article 5(1) Text}

\section{The risk of locked-in treaty text}

The advantages of the exhaustive nature of Article 5(1) of the draft Convention text also bring corresponding disadvantages. By attempting to be exhaustive, the Article 5(1) text runs both the risk of not going far enough, and the risk of going too far. The effort is exhaustive only with respect to situations that have been confronted up to this point in time. Given the dynamism of international trade - and the rapid process of change in concepts of legal persons, methods of communication, and technical means for the delivery of both content and services - it is not difficult to imagine that other bases of jurisdiction may become widely adopted, but remain outside the Convention. Nor is it difficult to imagine that existing bases of jurisdiction may no longer fit advancing technological methods. This approach thus risks locking in what may become outdated 
tests that can be changed only by treaty amendment - a process which is extremely difficult, particularly when (as is otherwise desirable) there are a large number of Contracting States.

\section{The risk of "homeward trend" interpretation}

The litigation predictability generated by an exhaustive list of jurisdictional filters also has its downside. While the Article 5(1) list may present a lawyer considering the best forum in which to bring an international case with the full set of indirect jurisdictional bases under the Convention, it also brings with it greater opportunity for non-uniformity of interpretation. Thus, while predictability is enhanced by having a fixed list, it is also diminished by having an elaborate and complex set of "uniform" which will be interpreted by multiple national courts. Because there is no single final court to provide binding interpretation of the Convention text, and because the courts of every Contracting State are likely to be subject to the "homeward trend" prevalent in other conventions which purport to provide "uniform" rules, ${ }^{30}$ the more indirect rules that are included in Article 5(1), the more likely that both predictability and uniformity of interpretation will suffer.

In the alternative, the narrowness of each jurisdictional filter may result in net predictability about the application of each rule, but reduced coverage of situations relevant to the evolving world of cross-border relationships. The alternative approach suggested above would result in the test for judgment circulation being determined by national courts based on their own rules of direct jurisdiction. These may evolve pragmatically to take account of new developments. Moreover, they would be delineated and applied by the courts of the state in which they apply, making non-uniform interpretations of the Convention text less likely.

30 Professor John Honnold first referred to the "homeward trend" in the interpretation of the United Nations Convention on Contracts for the International Sale of Goods (CISG). Decisions from Contracting States have not been consistent on every issue, and there have developed certain regional versions of the CISG as a result of judicial gloss. See, e.g., Harry M. Flechtner, Another CISG Case in the U.S. Courts: Pitfalls for the Practitioner and the Potential for Regionalized Interpretations, 15 J.L. \& COM. 127 (1995). 


\section{The risk of assuming effective legal system transfer}

While the May 2018 draft text of Article 5(1) may be predictable, and while such an approach may work well in national or regional internal legislation such as the Brussels I Regulation (where a single court will provide uniform interpretation), using the same approach in a global convention that is not easily subject to later amendment can be a source of potential problems. While the EU has demonstrated that the Brussels I Regulation may be updated and revised, that is not so easily accomplished with a treaty to which many more states are parties. The very specific nature of the language of each entry in Article 5(1) may well lock in terminology that, over the course of time, simply will not be capable of fair and reasonable application. What is appropriate in the law of a single federal entity is not necessarily appropriate in a global treaty.

\section{The risk of favoring discriminatory jurisdictional schemes over reciprocity}

In the Explanatory Note setting the stage for Special Commission consideration of the Judgments Convention draft text from the Working Group, one of the stated goals of a judgments convention was listed as the facilitation of international trade and investment by enhancing the free flow of judgments. ${ }^{31}$ In other words, this is more than a private international law convention; it is also a trade law convention.

A fundamental rule found in just about every trade treaty is a rule of non-discrimination. ${ }^{32}$ Contracting States take on reciprocal obligations in

${ }^{31}$ See, e.g., Hague Conference on Private International Law, Judgments Prel. Doc. No 2, Explanatory Note Providing Background on the Proposed Draft Text and Identifying Outstanding Issues (Apr. 2016) [hereinafter Prel. Doc. No 2] ("The Working Group proceeded on the basis that the future Convention is intended to pursue two goals:

- to enhance access to justice;

- to facilitate cross-border trade and investment, by reducing costs and risks associated with cross-border dealings.).

32 See, e.g., General Agreement on Tariffs and Trade art. III, opened for signature Oct. 30, 1947, 61 Stat. pts. 5 \& 6, T.I.A.S. No. 1700, 55 U.N.T.S. 187, reprinted in IV GATT, Basic Instruments and Selected Documents 1-78 (1969), as amended by the Final Act Embodying the Results of the Uruguay Round of Multilateral Trade Negotiations, Done at Marrakech, Apr. 15, 1994. See also 
order to create an international system that is fair and balanced. The May 2018 Draft Text does not include a rule of non-discrimination. Rather, through the choice of a specific set of rules of indirect jurisdiction in Article $5(1)$, it allows those states which discriminate in the process of judgments recognition to continue to do so. This results from the creation of a set of indirect jurisdiction rules which may be more limited than a Contracting State's corresponding set of direct jurisdiction rules. This will allow Member States to continue to allow the use of what are otherwise considered to be exorbitant bases of jurisdiction against foreign defendants in their own courts while at the same time refusing to recognize and enforce judgments brought on the same bases in foreign courts. ${ }^{33}$

The discriminatory jurisdiction gap problem is not a minor problem of the existing global system on recognition of judgments, and any global convention should address it. The May 2018 draft Convention text does not do so. A study done for the Working Group in 2015 listed the following countries as using the same test for direct jurisdiction as for indirect jurisdiction, and thus having no jurisdiction gap: ${ }^{34}$

Ronald A. Brand, New Challenges in the Recognition and Enforcement of Judgments, in The Continuing ReleVance of PRivate InTeRnational LaW AND ITS CHALlENGES (F. Ferrari \& Diego P. Fernandez Arroyo eds., Edward Elgar Publishing, forthcoming 2019).

${ }^{33}$ Such a discriminatory approach is clearly rejected in the internal EU system for recognition and enforcement of judgments through the operation of Article 5 of the Brussels I Recast Regulation, which allows defendants domiciled in Member States to be sued in other Member States only if one of the bases of jurisdiction listed in Sections 2 through 7 of the Regulation exists. With the resulting exclusive list of direct bases of jurisdiction, recognition and enforcement under Article 36 then occurs without consideration of jurisdiction in the court of origin, thus making the bases for direct and indirect jurisdiction exactly the same under the Regulation. Brussels I Recast Regulation, supra note 9.

${ }^{34}$ Comparative Study of Jurisdictional Gaps and Their Effect on the Judgments Project, memo of July 1, 2015 to Permanent Bureau of the Hague Conference on Private International Law, prepared by Mr. Charles Kotuby, partner at the law firm Jones Day, Washington, DC. See also Comparative Table on Grounds of Jurisdiction Prepared by the Permanent Bureau, January 2015. 


$\begin{array}{llll}\text { Albania } & \text { Chile } & \text { Israel } & \text { Luxembourg } \\ \text { Argentina } & \text { Germany } & \text { Italy } & \text { Mexico } \\ \text { Austria } & \text { Greece } & \text { Japan } & \text { Slovakia } \\ \text { Bulgaria } & \text { Hungary } & \text { Korea } & \text { United States } \\ \text { Canada } & \text { Ireland } & \text { Latvia } & \end{array}$

The same study found a jurisdiction gap in which direct bases of jurisdiction were more extensive than were indirect bases of jurisdiction in the following countries:

$\begin{array}{llll}\text { Australia } & \text { Ghana } & \text { Kazakhstan } & \text { Norway } \\ \text { Cyprus } & \text { Iceland } & \text { Kenya } & \text { Sweden } \\ \text { Denmark } & \text { Indonesia } & \text { New Zealand } & \text { UAE } \\ \text { Egypt } & \text { Jordan } & \text { Nigeria } & \text { United Kingdom }\end{array}$

The absence of a jurisdiction gap can be demonstrated by the judgments recognition systems in the United States, Germany, and Italy. In the United States, the general rule for recognition of judgments is found most often in state law in the form of a uniform act. ${ }^{35}$ The 2005 Uniform Foreign-Country Money Judgments Recognition Act, ${ }^{36}$ provides that a foreign money judgment which is final and enforceable in the country in which it is rendered, shall be recognized and enforced, ${ }^{37}$ subject to a limited list of grounds for non-recognition. ${ }^{38}$ One of the mandatory grounds for non-recognition is that "the foreign court did not have personal jurisdiction over the defendant." ${ }^{39}$ U.S. courts have uniformly interpreted this provision

${ }^{35}$ For more complete information on the U.S. system for the recognition of foreign judgments, see Ronald A. Brand, Federal Judicial Center International Litigation Guide: Recognition and Enforcement of Foreign Judgments, 74 U. PITT. L. REV. 491 (2013), https://papers.ssrn.com/sol3/papers.cfm?abstract_id=2443977.

36 National Conference of Commissioners on Uniform State Laws, Uniform Foreign-Country Money Judgments Recognition Act, https://www.uniformlaws.org/committees/communityhome/librarydocuments?communitykey=ae280c30-094a-4d8f-b7228dcd614a8f3e\&tab=librarydocuments.

${ }^{37}$ Id. art. 4(a).

${ }^{38} \mathrm{Id}$. art. 4(b) and (c).

${ }^{39}$ Id. art. 4(b)(2). 
of the Uniform Act (and of the common law test without the Uniform Act) to mean the foreign court must have had jurisdiction according to U.S. tests of personal jurisdiction. ${ }^{40}$ This means that, if the facts before the foreign court would have satisfied the tests a U.S. court applies in determining direct jurisdiction, then the U.S. court addressed for purposes of recognition and enforcement, will accept that judgment, subject to specific listed grounds for non-recognition. There is no difference between the test for direct jurisdiction and the test for indirect jurisdiction.

The same is true in German courts faced with a request for recognition and enforcement of a judgment from outside the European Union. ${ }^{41}$ Section 328(I) of the German Code of Civil Procedure includes a requirement that the foreign court from which a judgment originates had "jurisdiction under German law."42 In Italy, Article 64 of Law 218/1995, is similar on this issue, requiring that, for recognition of a foreign judgment to occur, "the authority rendering the judgement had jurisdiction pursuant to the criteria of jurisdiction in force under Italian law." 43 In each of these instances, the rules of direct jurisdiction are applied as the rules of indirect jurisdiction. This means that, so long as the case could have been brought in

40

The prevailing view is that, even if the rendering court had jurisdiction under the laws of its own state, a court in the United States asked to recognize a foreign judgment should scrutinize the basis for asserting jurisdiction in the light of American concepts of jurisdiction to adjudicate. International Shoe and its progeny govern this determination.

Ronald A. BRAnd, InTERnational Business Transactions Fundamentals ch. 6 (2d ed. 2018). See, e.g., Mercandino v. Devoe \& Raynolds, Inc., 181 N.J. Super. 105, 108, 436 A.2d 942 (App. Div. 1981) ("In determining whether the Italian court had jurisdiction we deem it appropriate to apply the minimum contacts test.”).

${ }^{41}$ Judgments from within the EU are governed by the Brussels I Recast Regulation. Brussels I Recast Regulation, supra note 9.

42 See I Philip Weems, Enforcement of Money Judgments Abroad FRG-29 (1993).

${ }^{43}$ Article 64(1)(a) of Law 218/1995, Italy. 
the recognizing state on similar jurisdictional facts, the court addressed will accept that jurisdiction was proper in the court of origin.

This is not the case in those countries which have a broader list for direct jurisdiction than for indirect jurisdiction purposes. An example of such a discriminatory jurisdiction gap is found in the United Kingdom. There, the direct jurisdiction rules are found in Practice Direction 6B which accompanies Part 6 of the Civil Procedure Rules 1998 of the Supreme Court of England and Wales (CPR). The Practice Direction provides a court with discretion to order service outside the jurisdiction of the United Kingdom in a number of specific situations. ${ }^{44}$ The Practice Direction lists

${ }^{44}$ Practice Direction 6:

Service out of the jurisdiction where permission is required

3.1 The claimant may serve a claim form out of the jurisdiction with the permission of the court under rule 6.36 where -

General Grounds

(1) A claim is made for a remedy against a person domiciled within the jurisdiction.

(2) A claim is made for an injunction(GL) ordering the defendant to do or refrain from doing an act within the jurisdiction.

(3) A claim is made against a person ('the defendant') on whom the claim form has been or will be served (otherwise than in reliance on this paragraph) and -

(a) there is between the claimant and the defendant a real issue which it is reasonable for the court to try; and

(b) the claimant wishes to serve the claim form on another person who is a necessary or proper party to that claim.

(4) A claim is an additional claim under Part 20 and the person to be served is a necessary or proper party to the claim or additional claim.

(4A) A claim is made against the defendant in reliance on one or more of paragraphs (2), (6) to (16), (19) or (21) and a further claim is made against the same defendant which arises out of the same or closely connected facts. 
Claims for interim remedies

(5) A claim is made for an interim remedy under section 25(1) of the Civil Jurisdiction and Judgments Act 1982.

Claims in relation to contracts

(6) A claim is made in respect of a contract where the contract -

(a) was made within the jurisdiction;

(b) was made by or through an agent trading or residing within the jurisdiction;

(c) is governed by English law; or

(d) contains a term to the effect that the court shall have jurisdiction to determine any claim in respect of the contract.

(7) A claim is made in respect of a breach of contract committed within the jurisdiction.

(8) A claim is made for a declaration that no contract exists where, if the contract was found to exist, it would comply with the conditions set out in paragraph (6).

Claims in tort

(9) A claim is made in tort where -

(a) damage was sustained, or will be sustained, within the jurisdiction; or

(b) damage which has been or will be sustained results from an act committed, or likely to be committed, within the jurisdiction.

Enforcement

(10) A claim is made to enforce any judgment or arbitral award. 
Claims about property within the jurisdiction

(11) The subject matter of the claim relates wholly or principally to property within the jurisdiction, provided that nothing under this paragraph shall render justiciable the title to or the right to possession of immovable property outside England and Wales.

Claims about trusts etc.

(12) A claim is made in respect of a trust which is created by the operation of a statute, or by a written instrument, or created orally and evidenced in writing, and which is governed by the law of England and Wales.

(12A) A claim is made in respect of a trust which is created by the operation of a statute, or by a written instrument, or created orally and evidenced in writing, and which provides that jurisdiction in respect of such a claim shall be conferred upon the courts of England and Wales.

(13) A claim is made for any remedy which might be obtained in proceedings for the administration of the estate of a person who died domiciled within the jurisdiction or whose estate includes assets within the jurisdiction.

(14) A probate claim or a claim for the rectification of a will.

(15) A claim is made against the defendant as constructive trustee, or as trustee of a resulting trust, where the claim arises out of acts committed or events occurring within the jurisdiction or relates to assets within the jurisdiction.

(16) A claim is made for restitution where -

(a) the defendant's alleged liability arises out of acts committed within the jurisdiction; or

(b) the enrichment is obtained within the jurisdiction; or

(c) the claim is governed by the law of England and Wales.

Claims by HM Revenue and Customs

(17) A claim is made by the Commissioners for H.M. Revenue and Customs relating to duties or taxes against a defendant not domiciled in Scotland or Northern Ireland. 
twenty-one connecting factors, each of which may justify service outside the jurisdiction and thus constitute an acceptable basis of jurisdiction over a

Claim for costs order in favour of or against third parties

(18) A claim is made by a party to proceedings for an order that the court exercise its power under section 51 of the Senior Courts Act 1981 to make a costs order in favour of or against a person who is not a party to those proceedings.

(Rule 46.2 sets out the procedure where the court is considering whether to exercise its discretion to make a costs order in favour of or against a non-party.)

Admiralty claims

(19) A claim is -

(a) in the nature of salvage and any part of the services took place within the jurisdiction; or

(b) to enforce a claim under section $153,154,175$ or $176 \mathrm{~A}$ of the Merchant Shipping Act 1995.

Claims under various enactments

(20) A claim is made -

(a) under an enactment which allows proceedings to be brought and those proceedings are not covered by any of the other grounds referred to in this paragraph; or

(b) under the Directive of the Council of the European Communities dated 15 March 1976 No. 76/308/EEC, where service is to be effected in a Member State of the European Union.

Claims for breach of confidence or misuse of private information

(21) A claim is made for breach of confidence or misuse of private information where

(a) detriment was suffered, or will be suffered, within the jurisdiction; or

(b) detriment which has been, or will be, suffered results from an act committed, or likely to be committed, within the jurisdiction. 
foreign defendant. The same is not true when a UK court tests the jurisdiction of a foreign court when a judgment is brought for recognition and enforcement. In that latter event, UK courts apply "The Dicey Rule," found in the most recent edition of Dicey \& Morris, The Conflict of Laws. ${ }^{45}$ That test provides for only four grounds of indirect jurisdiction. ${ }^{46}$ The result could be interpreted either as acknowledgment that the longer list of direct bases of jurisdiction found in Practice Direction 6B contains otherwise questionable bases of jurisdiction, or that there is a desire to discriminate against judgments from foreign courts.

The alternative approach to Article 5(1) suggested above would effectively prevent a jurisdiction gap by making the grounds for indirect jurisdiction in each Contracting State exactly the same as that state's grounds for direct jurisdiction - for judgments coming from courts of other Contracting States. This would mean that the rules for recognition and

45 DiCey \& Morris, The CONFLiCT Of LAws, Rule 43 (14R-054) (15th ed. 2012). See, e.g., Rubin v. Eurofinance SA, [2012] UKSC 46, at ๆף 7-10, in which Lord Collins, the General Editor of Dicey \& Morris, follows the "Dicey Test," and traces its history.

46 DICEY \& MORRIS, supra note 45, Rule 43:

Rule 43 - Subject to Rules 44 to 46 , a court of a foreign country outside the United Kingdom has jurisdiction to give a judgment in personam capable of enforcement or recognition as against the person against whom it was given in the following cases:

First Case - If the person against whom the judgment was given was, at the time the proceedings were instituted, present in the foreign country.

Second Case - If the person against whom the judgment was given was claimant, or counterclaimed, in the proceedings in the foreign court.

Third Case - If the person against whom the judgment was given, submitted to the jurisdiction of that court by voluntarily appearing in the proceedings.

Fourth Case - If the person against whom the judgment was given, had before the commencement of the proceedings agreed, in respect of the subject matter of the proceedings, to submit to the jurisdiction of that court or of the courts of that country. 
enforcement in each Contracting State could differ from those in other Contracting States, but they would be consistent with each Contracting State's rules for direct jurisdiction. Parties to litigation in which recognition and enforcement may be required in other Contracting States would logically begin by looking at the first three bases for judgment circulation in the alternative list. This alone would create some channeling of litigation into those three more favored approaches to jurisdiction. Beyond that, parties to international litigation would then consider the grounds for direct jurisdiction in the state or states in which recognition or enforcement may be required. This final step is no different from what is currently necessary when recognition and enforcement may be required in a country in which there is no jurisdiction gap.

Whether one is concerned with simple fairness and preventing discrimination, or with the normal process of reciprocity common to international trade treaties, the fact that the May 2018 draft Judgments Convention text would lock in discriminatory jurisdiction gaps in the states in which they currently exist is a matter which should be considered carefully before a final Convention text is approved.

\section{The risk of a diminished channeling function}

The other goal of a Judgments Convention which was noted in the Permanent Bureau Report to the first Special Commission is the possibility of improving the litigation landscape through "access to justice" for parties considering or involved in cross-border litigation. ${ }^{47}$ Access to justice is a judgments recognition issue, but it is first a direct jurisdiction issue. This raises the question of how a judgments convention might impact questions of direct jurisdiction, otherwise than by possibly setting up a later negotiation of a jurisdiction convention.

Other than the Article 6 incorporation of specific bases of exclusive jurisdiction, and their use to provide grounds for prohibition of recognition even outside the Convention, the May 2018 draft Judgments Convention text does not explicitly affect rules of direct jurisdiction. A functioning Judgments Convention can, however, have an impact on national rules of jurisdiction through a channeling effect which may occur even in the absence of a separate jurisdiction convention. Litigators bringing claims

\footnotetext{
${ }^{47}$ Prel. Doc. No 2, supra note 31.
} 
which may require judgment recognition in a country other than that of the court of origin will necessarily consider the bases of direct jurisdiction which can result in circulation of their judgment under a Convention. Their litigation conduct will be channeled into widely accepted bases of jurisdiction.

If a Convention is built on rules of indirect jurisdiction - as is the May 2018 text - those rules should also be considered by litigators at the outset, and should channel cases to courts in which acceptable bases of jurisdiction exist for both direct and indirect jurisdiction purposes. A list of thirteen indirect jurisdiction bases in Article 5(1) limits the possibilities of achieving this channeling function. The list does encourage bringing cases which satisfy one of the jurisdictional bases on the list. As noted earlier, however, it also sets up rather complex rules that may result in different interpretations of those jurisdictional bases in the courts of different Contracting States - thus limiting predictability and risking non-recognition even though the court of origin finds the jurisdictional basis to exist.

An alternative based on a simple non-discrimination rule should encourage cases to be brought based on the direct jurisdiction rules most common to countries in which recognition and enforcement might be sought. Over time, this may cause Contracting States to reassess their bases of direct jurisdiction, and serve as well to provide a channeling effect that could result in the reduction of the number of exorbitant bases of jurisdiction existing in those states. This may be only an indirect way of achieving what might otherwise be done by a jurisdiction convention, but, given the problems which prevented coalescence on rules of direct jurisdiction in the Hague 1999 and 2001 drafts of a comprehensive jurisdiction and judgments convention (which problems largely continue to remain), it may be a more palatable and likely way of achieving that result.

\section{Comparing the Alternatives}

The advantages of the approach found in Article 5(1) of the draft text of May 2018 may be summarized as follows:

1) it provides an exhaustive list of available indirect bases of jurisdiction;

2) it creates predictability in international litigation by having the list available when a case is initiated; and

3) it conforms to the predominant legal system model - that of the continental European civil law legal system. 
In comparison to the May 2018 draft text of Article 5(1), the alternative approach suggested above would diminish or eliminate:

1) the risk of an exhaustive list which locks in what may become outdated tests that can be changed only by difficult treaty amendment;

2) the risk of diminishing predictability through national court interpretation and the attendant "homeward trend" that has been evident in similar conventions which provide "uniform" rules;

3) the risk of assuming that effective national or regional legal frameworks can automatically be implemented on a global basis;

4) the risk of retention and endorsement of discriminatory jurisdictional schemes applied to judgments recognition rules, thus avoiding normal international trade treaty concepts of reciprocity: and

5) the risk of a diminished channeling function that might otherwise be achieved under a system that encourages uniformity of direct and indirect bases of jurisdiction.

Consistently more rapid technological developments have a significant impact on both what is exchanged across borders and the manner in which it is exchanged. Those developments also have an impact on legal rules dealing with disputes which arise from those exchanges. More-and-more, we are confronted with a borderless world in which jurisdictional rules require reference to territorial concepts. While people and goods could easily be identified to exist within the physical borders of states in the nineteenth century, developments in legal personality, intellectual property rights, financial services, and other elements of international trade, cause both legal persons and relevant legal concepts to exist in many places (and many states) at once, without clear deference to state authority defined by lines drawn on maps.

Jurisdictional rules based on the place of performance of a contract or the place of injury resulting from a tort now often require the reification of concepts in order to treat them as if they are things that exist within physical borders. In other words, they require reference to legal fictions. This may simply be a matter of necessity, but, as the Member States of the Hague Conference prepare a Judgments Convention for the future, it is 
important that the result not be a nineteenth century instrument to be used to solve twenty-first century problems.

It may be that some of the problems discussed above can be reduced through the operation of Article 16 of the May 2018 draft Judgments Convention text. That provision provides that: "Subject to Article 6, this Convention does not prevent the recognition or enforcement of judgments under national law."

This allows Contracting States to continue to apply rules on the recognition and enforcement of foreign judgments which are more liberal than those in the Convention text. That, however, only increases the discriminatory effect of the May 2018 draft text. Those Contracting States without a jurisdiction gap, in which judgments beyond the May 2018 draft text rules could be recognized and enforced as consistent with the direct jurisdiction rules in the state addressed, would continue to give effect to foreign judgments from other Contracting States. Those Contracting States with a jurisdiction gap are less likely to use the freedom of Article 16 to recognize and enforce judgments outside the Convention framework. The very basic reciprocity expected of treaty relationships would thus be frustrated.

It may be that there is no single best text. Legal systems in some countries may best fit the approach taken in the May 2018 draft Judgments Convention text, while other systems may better fit an approach with the benefits of the alternative suggested above. This is not necessarily a bad result. It is entirely possible that movement toward greater free movement of judgments can occur on two fronts simultaneously. For example, the May 2018 text could move forward to a final Convention text at a Diplomatic Conference in 2019. That text could become the source of greater multilateral judgments recognition among countries which would sign and ratify. At the same time, an alternative text along the lines presented above might well draw to it countries that find the impact of the May 2018 text to be less than ideal. Other countries might find it desirable to become party to both types of conventions.

\section{The Difficult Political Question}

One issue the May 2018 draft Judgments Convention text has not yet fully addressed is the question sometimes referred as "mutual trust." 48 This

${ }^{48}$ See, e.g., Andreas Bonomi, New Challenges in the Context of Recognition and Enforcement of Judgments, in The Continuing Relevance of PRIVATE 
issue was addressed in the 1971 Hague Judgments Convention by requiring not only general ratification of the Convention text, but also separate bilateralization of Contracting State obligations through declarations regarding the other Contracting States to which each Contracting State would apply the benefits of the Convention. ${ }^{49}$ Only five countries have ratified or acceded to that Convention, with no indication that the required separate bilateral agreements have been reached to put the treaty into force in an effective way between any of those Contracting States. ${ }^{50}$

The structure of the 1971 Judgments Convention demonstrates that countries may be hesitant to ratify a judgments convention which allows any other country to join and automatically receive reciprocal benefits. So far, the Hague Judgments Project has not directly faced this issue. This is perhaps a political matter more appropriately addressed in a Diplomatic Conference than in a Special Commission. It will, nonetheless, require direct consideration, and the adoption of a specific treaty approach.

If the Diplomatic Conference in 2019 retains the architecture found in the May 2018 Draft Text - and in particular if no internal system is included in the final Convention text for dealing with the mutual trust issue - then the alternative approach to Convention architecture suggested above may well provide a useful text for a separate network of bilateral judgments recognition treaties; or even for a second multilateral treaty. Having such an alternative available to a Hague Convention text may well result in additional, if not greater, progress toward the goal of global circulation of civil and commercial judgments. While this approach may

International LAw And Its Challenges (F. Ferrari \& Diego P. Fernandez Arroyo eds., Edward Elgar Publishing, forthcoming 2019).

${ }^{49}$ Hague Conference on Private International Law, Convention of 1 February 1971 on the Recognition and Enforcement of Foreign Judgments in Civil and Commercial Matters,

https://www.hcch.net/en/instruments/conventions/full-text/?cid=78. Article 21 of the 1971 Convention provides that "Decisions rendered in a Contracting State shall not be recognised or enforced in another Contracting State in accordance with the provisions of the preceding Articles unless the two States, being Parties to this Convention, have concluded a Supplementary Agreement to this effect.”

${ }^{50}$ See HCCH, Status Table, https://www.hcch.net/en/instruments/conventions/status-table/?cid=78. 
not maximize participation in a Hague Conference instrument, it could serve Hague Conference goals, and supplement the enhanced circulation of judgments that may result from a Hague Judgments Convention with more limited membership.

\section{CONCLUSION}

The May 2018 draft text for a Hague Convention on the Recognition and Enforcement of Judgments in Civil and Commercial Matters indicates a clear choice for an approach that carries with it a number of risks, including a significant risk of non-uniform interpretation over the life of the treaty. That risk results in particular from the long list of jurisdictional filters found in Article 5(1) of the Convention. While this approach to convention architecture may be the best approach, full consideration of an alternative has not occurred since early in the negotiating process, when only a small Working Group was involved and the Article 5(1) list was shorter and less complicated. It may well be that the choices which have been made provide the best approach to a global judgments recognition convention. Nonetheless, failure to fully compare the current approach - as it has been more fully developed by the Special Commission - against the alternative which was passed over when drafting was at a much earlier stage, may not be prudent.

Moreover, it may well prove valuable to have two judgments convention models available for Hague Conference Member States (whether officially through the Hague Conference system or not). Even if the approach taken in the May 2018 draft Judgments Convention text moves forward, some countries may find it more palatable to enter into bilateral or multilateral judgments recognition treaties which offer an approach that avoids some of the risks presented in the May 2018 draft text, as well as present other benefits over the draft Hague text. 